\title{
Evaluation of water quality parameters for monitoring natural, urban, and agricultural areas in the Brazilian Cerrado
}

\author{
Avaliação de parâmetros de qualidade de água para monitoramento \\ de áreas naturais, urbanas e agrícolas no Cerrado brasileiro
}

\section{Daphne Heloisa de Freitas Muniz ${ }^{1}$, Aline Silva Moraes², Ingrid de Souza Freire², Carlos José Domingos da Cruz ${ }^{1}$, Jorge Enoch Furquim Werneck Lima ${ }^{1}$ and \\ Eduardo Cyrino Oliveira-Filho ${ }^{1}$}

${ }^{1}$ Laboratório de Ecotoxicologia, Embrapa Cerrados, CEP 73310-970, Planaltina, DF, Brazil e-mail: daphne.muniz@cpac.embrapa.br; karl.edward@gmail.com; jorge@cpac.embrapa.br; cyrino@cpac.embrapa.br ${ }^{2}$ Centro Universitário de Brasília - UniCEUB, CEP 70790-075, Brasília, DF, Brazil e-mail: alinesilvamoraes_df@yahoo.com.br; ingridfgen@gmail.com

\begin{abstract}
Introduction: Brazil's Federal District (FD) has seen steep population growth in recent years, and this has increased demand for high-quality water. Aim:The present work aims to evaluate the quality of surface water from two water bodies in the FD at six sampling points, three of which are in the Sobradinho River (the receiving body of a sewage treatment plant effluent) and three in the Jardim River (located in an agricultural region). Methods: Analyses were carried out every thirty days, for twelve months, covering rainy and dry seasons. Parameters were analyzed such as temperature, $\mathrm{pH}$, dissolved oxygen (DO), conductivity, turbidity, total hardness, main ions, total and fecal coliforms (E. coli) in water. Ecotoxicological evaluation was also performed, using the micro-crustacean Ceriodaphnia dubia. Results: Data of physical and chemical determinations showed DO, conductivity, $\mathrm{Cl}^{-}, \mathrm{NO}_{3}^{-}, \mathrm{SO}_{4}^{2-}$ and $\mathrm{Na}^{+}$to be important in indicating contamination by urban effluents. On the subject of biological parameters $-E$. coli and ecotoxicological evaluation - the former was seen to be more effective in the urban area. However, in the countryside, the assay with $C$. dubia proved to be the most sensitive, although less than ideal, because the organism is very sensitive to low water hardness. Conclusions: The fecal coliform indicator $(E$. coli) was the most effective one for comparing water quality in the two basins, mainly for the urbanized one, while ecotoxicity assays with $C$. dubia were harmed by the natural chemical composition of the water.
\end{abstract}

Keywords: water hardness, ecotoxicology, water resources, calcium, bioindicators.

Resumo: Introduçáo: O Distrito Federal (DF) tem apresentado grande crescimento populacional nos últimos anos, o que vem ocasionando aumento da necessidade por água de qualidade, tanto pelas cidades quanto pela área rural. Objetivo: $\mathrm{O}$ presente trabalho teve como objetivo avaliar a qualidade da água superficial de dois corpos hídricos no DF em seis pontos de amostragem, três localizados no Ribeirão Sobradinho (corpo receptor de Estação de Tratamento de Esgoto) e três no Alto Rio Jardim (regiáo com forte atividade agrícola). Métodos: Análises de temperatura, $\mathrm{pH}$, oxigênio dissolvido (OD), condutividade, turbidez, dureza total, principais íons, coliformes totais e fecais (E. coli) da água, foram realizadas mensalmente durante doze meses envolvendo períodos seco e chuvoso. Além disso, também foi realizada avaliação ecotoxicológica utilizando o microcrustáceo Ceriodaphnia dubia. Resultados: Os dados físico-químicos mostraram que $\mathrm{OD}$, condutividade, $\mathrm{Cl}^{-}, \mathrm{NO}_{3}^{-}, \mathrm{SO}_{4}^{2-}$ e $\mathrm{Na}^{+}$foram importantes para indicar a contaminação por efluentes urbanos. Quanto aos parâmetros biológicos, E. coli e avaliação ecotoxicológica, observou-se que o primeiro foi mais efetivo para avaliar qualidade da água na área urbana, enquanto que na área rural, o ensaio com $C$. dubia mostrou-se mais sensível, mas não ideal, tendo em vista a alta sensibilidade do organismo à baixa dureza da água. Conclusóes: A presença de coliformes fecais (E. coli) foi o indicador mais efetivo para comparar a qualidade da água entre as duas bacias, principalmente na urbanizada, enquanto que os ensaios de ecotoxicidade com $C$. dubia foram prejudicados pela composição química natural da água.

Palavras-chave: dureza da água, ecotoxicologia, recursos hídricos, cálcio, bioindicadores. 


\section{Introduction}

Water is a natural resource that is fundamental to maintaining life. Water ecosystems have undergone profound changes in recent years, mainly due to human activities, at a range of levels. These ecosystems receive a large variety and quantity of pollutants, either through the soil or by being directly discharged into water, with subsequent impact both on the environment and on human health (Oliveira-Filho and Parron, 2007).

The Cerrado (Brazilian savanna) is the second largest Brazilian biome (204 million ha) and due to its location in the Brazilian Central Plateau it plays an important role in terms of water production and distribution throughout the country. Eight of the twelve Brazilian hydrographic regions receive water from this biome. Therefore, knowledge about hydrological processes and their interactions with human activities in this region is fundamental in terms of both economics and ecology (Lima and Silva, 2008). The Federal District (FD) of Brazil has seen steep population growth in the last two decades, and this rise has increased the need for water, even generating conflicts over the use and sourcing of non-contaminated supplies. The main sanitary sources of contamination in the District's water bodies come from domestic effluents, sewage treatment plants, garbage dumps and cemeteries; the main farming sources stem from the frequent use and handling of pesticides, fertilizers and manure; services are also involved, such as gasoline stations, bus depots, and industries, albeit few in number (Barros, 2005).

In the process of contaminating water resources, agriculture poses a threat in its use of pesticides and fertilizers, which can reach underground water by infiltrating the soil, or which may drain directly into rivers with surface runoff water (Oliveira-Filho and Lima, 2002). However, contamination of water in urban areas is mainly due to domestic sewage. This is continuous and highly polluting, and it is also closely linked to the spread of human water-borne diseases. In Brazil, sewage is a major cause of water pollution. Data from a recent study by the World Health Organization show that in 23 countries, including Brazil, more than $10 \%$ of infant mortality is linked to water contamination (WHO, 2007).

Determining water quality has been adopted as one of the main criteria for the establishment of water use, because these standards seek, above all, the safety of the consumer population. This is due to the fact that water quality is not necessarily a state of purity, but is configured by its chemical, physiological and biological characteristics (Merten and Minella, 2002). Studies that include monitoring of aquatic ecosystems are essential for the accumulation of information and knowledge about the quality of water bodies. Understanding the importance of water quality for human life is fundamental and it imposes the need to transfer data and information to the public, on how to take advantage of and conserve this natural resource with the objective of obtaining sustainability (OliveiraFilho and Parron, 2007).

The purpose of the current study was to evaluate surface water quality parameters in natural, urban and agricultural areas of the Brazilian Cerrado. Thus, data and indicators can be qualified, so as to define the best strategies for monitoring water quality in this important hotspot of the world.

\section{Material and Methods}

\subsection{Study areas}

Study areas are presented in Figure 1. The Sobradinho River, an important tributary of the São Bartolomeu River, is part of the fundamental drainage network for the FD and, although it does not supply the local population with drinking water, it dilutes domestic effluents and follows its course to contribute to the flow of large rivers. With respect to aspects of land use and occupation, the outstanding feature of this area is the intense process of land subdivision, which intensified especially in the 90's. Currently the region is densely populated and contains some of the older housing complexes and condos of the FD (Zoby and Duarte, 2001). The Sobradinho River has undergone environmental changes due to urban expansion and consequent pollution. In addition, part of the sewage from the town of Sobradinho is thrown untreated into its waters (CAESB, 2008). A study carried out by Shibano et al. (2000) evaluated water quality in 39 places in the FD, including at two points in the Sobradinho River (before and after it receives the effluent from the sewage treatment plant). At the point just after the effluent the study showed high electrical conductivity and concentrations of chemicals, such as nitrate, sodium, chloride and sulfate.

The hydrographic basin of the Jardim River (FD) is the main sub-basin of the Preto River in the district. It covers an area of $540 \mathrm{~km}^{2}$ and is important for growing grain crops (mainly maize, soybean, wheat and dry and irrigated beans), being an area eminently suitable for agricultural 


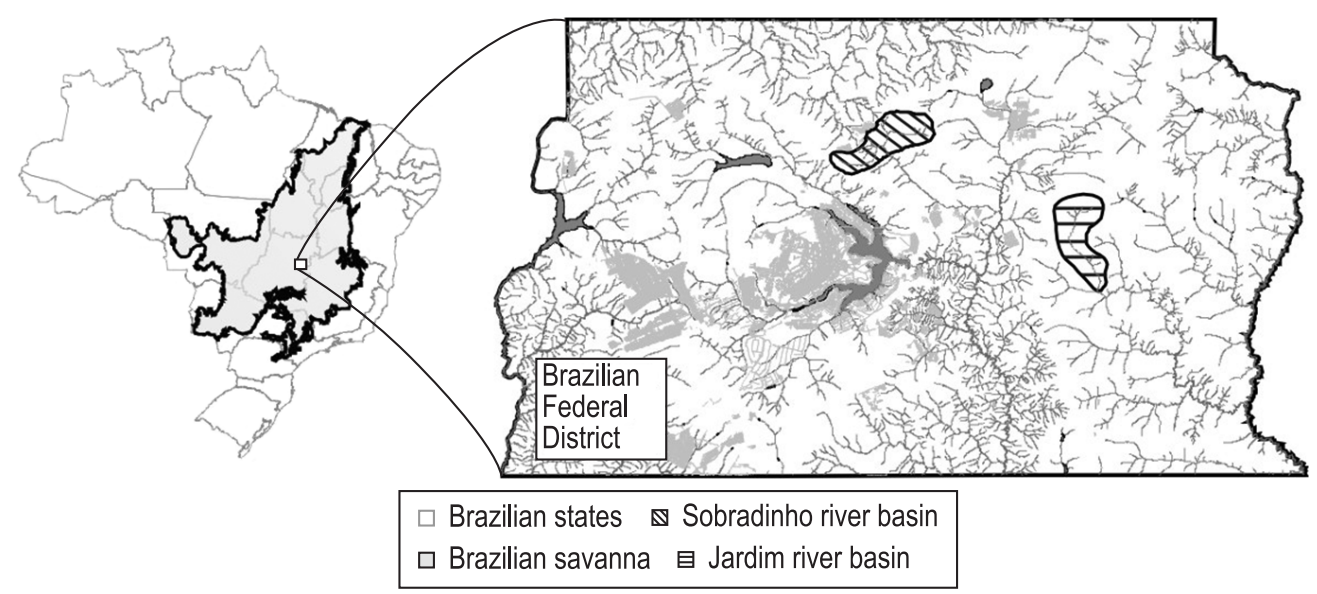

Figure 1. Geographical localization of the study areas.

use (Lima, 2010). There have been few studies reporting the effect of using fertilizers and pesticides on the quality of surface water from the Jardim River. The large agricultural area in the region has led to substantial amounts of chemical products being used in the interests of maintaining high productivity. Abuse of these applications can result in contamination and increased residues in the crops. In a recent study, Luiz et al. (2007) detected variations in the levels of nitrate in underground water from the region, especially in rainy periods.

The climate of the Brazilian Federal District is typical of the Cerrado region, showing two well defined seasons: a rainy summer and a dry winter. The dry season starts from March to April and usually ends in September or October. In the other months rains can be heavy. The total annual average rainfall of the area varies from about 1,200 to $1,700 \mathrm{~mm}$, with more than $84 \%$ of the rain usually occurring between October and April (Fonseca, 2001).

\subsection{Sampling}

The water samples were collected at six sites distributed in the studied areas. P1 was defined as the source of the Sobradinho River ( $15^{\circ} 37^{\prime} 59^{\prime \prime} \mathrm{S}$ and $\left.47^{\circ} 46^{\prime} 21^{\prime \prime} \mathrm{W}\right), \mathrm{P} 2$ was upstream of the Sobradinho Sewage Treatment Plant (STP) in the middle of the town of Sobradinho (15 38' $37^{\prime \prime}$ S and $\left.47^{\circ} 48^{\prime} 44^{\prime \prime} \mathrm{W}\right), \mathrm{P} 3$ was downstream of the STP (15 39' $37^{\prime \prime} \mathrm{S}$ and $\left.47^{\circ} 48^{\prime} 32^{\prime \prime} \mathrm{W}\right)$, P4 was defined as the source of the Jardim River ( $15^{\circ} 43^{\prime} 51^{\prime \prime} \mathrm{S}$ and $47^{\circ} 34^{\prime} 42^{\prime}$ W), P5 was upstream of the dam of the Jardim River ( $15^{\circ} 45^{\prime} 55^{\prime \prime} \mathrm{S}$ and $\left.47^{\circ} 35^{\prime} 34^{\prime \prime} \mathrm{W}\right)$ and P6 was upstream of the confluence of the Jardim River and Estanislau Creek (15 49' 44" $\mathrm{S}$ and $47^{\circ} 33^{\prime} 29^{\prime \prime} \mathrm{W}$ ) (Figure 2). Sampling was performed by submerging a collector to a depth of 15 to $20 \mathrm{~cm}$, and the samples were transferred to polyethylene flasks. To determine total coliforms and E. coli, the samples were collected in flasks containing sodium thiosulfate. The samples were collected every thirty days for twelve consecutive months, from May 2008 to April 2009.

Physical, chemical, biological analyses and ecotoxicological assays were carried out with each sample. After being collected, all samples destined for toxicity assays were kept refrigerated until being tested. All sampling and preservation procedures and analytical methodologies followed the criteria adopted by the APHA (1998).

\subsection{Physical and chemical analyses of water}

The parameters temperature, dissolved oxygen (DO), $\mathrm{pH}$ and electrical conductivity were determined in the field, in unfiltered samples, using a multi-parameter portable HI 9828 measure (Hanna inst., USA). Turbidity tests were carried out in the laboratory, on the collection day, with a turbidimeter model HI 93703 (Hanna inst., USA). Analysis of total hardness was done in the laboratory using the titulometric method by EDTA-Na (ABNT 1992). In samples filtered through a membrane filter $(0.45 \mu \mathrm{m})$ anion content was determined for chloride $\left(\mathrm{Cl}^{-}\right)$, nitrate $\left(\mathrm{NO}_{3}^{-}\right)$, phosphate $\left(\mathrm{PO}_{4}^{3-}\right)$ and sulfate $\left(\mathrm{SO}_{4}^{2-}\right)$; and for cations: sodium $\left(\mathrm{Na}^{+}\right)$, ammonium $\left(\mathrm{NH}_{4}^{+}\right)$, calcium $\left(\mathrm{Ca}^{2+}\right)$ and magnesium $\left(\mathrm{Mg}^{2+}\right)$, by ion chromatography using the 761Compact IC chromatograph (Metrohm AG, Switzerland). Chromatographic analyses were performed in the Water Chemistry Laboratory at Embrapa Cerrados. 

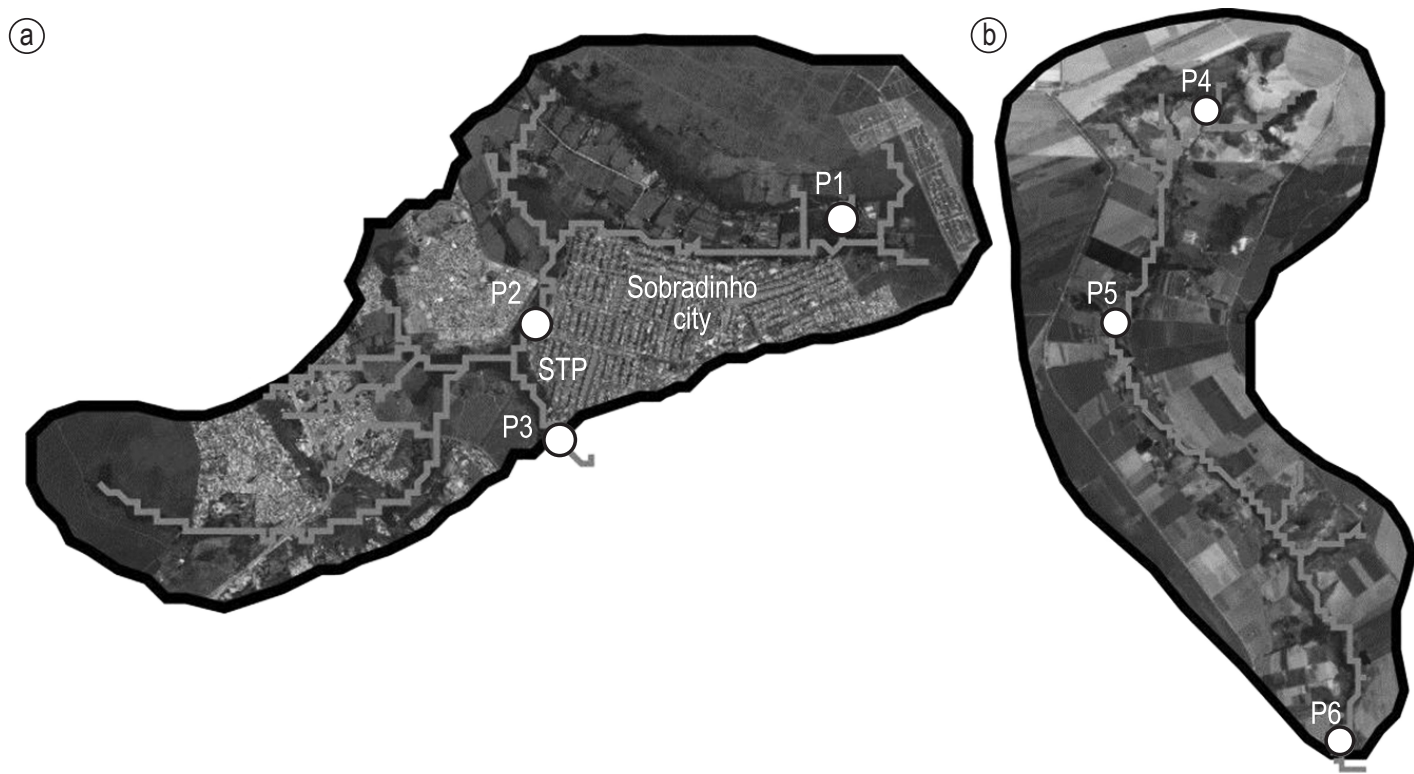

Figure 2. Land use and water sampling points in the Sobradinho river basin, showing urban land use (a) and in the Jardim river basin, showing agricultural land use (b).

\subsection{Analysis of total coliforms and Escherichia coli}

The measurements for total coliforms and E. coli were carried out in the Ecotoxicology Laboratory at Embrapa Cerrados, using the chromogenic method (Colilert ${ }^{\oplus}$, Idexx), as described in Standard Methods for Water and Wastewater (APHA, 1998).

\subsection{Ceriodaphnia dubia maintenance}

The microcrustaceans from species Ceriodaphnia dubia Richard, 1894 (Cladocera, Crustacea) used in the study were obtained in cultures maintained in the Ecotoxicology Laboratory at Embrapa Cerrados, Brazil. The cultures were kept in an incubator at a controlled temperature $\left(25 \pm 1{ }^{\circ} \mathrm{C}\right)$ with photoperiod of 12 hours light/12 hours dark and light intensity of approximately 1100 lux. The culture water used was synthetic soft water with $\mathrm{pH} 7.2 \pm 0.2$, with hardness between 40 and $48 \mathrm{mg} . \mathrm{L}^{-1} \mathrm{CaCO}_{3}$ and DO above $95 \%$. The organisms were fed daily with an algal suspension of Pseudokirchneriella subcapitata (Korshikov) Hindák, 1990, formerly known as Selenastrum capricornutum, at a concentration of $2 \times 10^{5}$ cells. $\mathrm{mL}^{-1}$. The sensitivity of the C. dubia culture was tested with sodium chloride $(\mathrm{NaCl})$ as a reference substance (ABNT, 2003).

\subsection{Assays with C. dubia}

The assay consisted of exposure of young individuals to surface water from the sample sites (Sobradinho and Jardim Rivers) and a control group exposed to synthetic soft water, for a period of seven to eight days. The assays were kept under the same temperature and photoperiod as the culture. Beakers of $30 \mathrm{~mL}$ were used as assay receptacle, with a final volume of $15 \mathrm{~mL}$ of gross sample. Each sample presented 10 replicates, with one organism in each replicate. Every 24 hours the F0 organisms (parents) were transferred, using a Pasteur pipette, to new beakers with sample and food. This was renewed daily with $P$. subcapitata algae and fermented fishfood with a total solid content of between 2.5 and 3.1 g. $\mathrm{L}^{-1}$. The assays were validated when the survival of the control group was equal to or above $80 \%$. The average number of offspring produced per female and the number of surviving adult females were determined at the end of the exposure period, for later evaluation of possible effects on survival and reproduction of the organisms.

\subsection{Statistical analysis of the ecotoxicological assays}

Analysis of the results was established by comparing survival rates of the organisms in each sample with those from the control group. This same comparison was also carried out for the average number of juvenile organisms produced to establish significant differences. When there was no statistical difference the result was expressed as "Non-Toxic" (NT), while a result with a significant statistical difference was expressed as "toxic". When mortality occurred within 48 hours, with significant difference, the result was expressed as "Acute Toxicity" (AT), and when there was a significant 
difference between the number of offspring in the control group and the number of offspring in the test groups, the result was expressed as "Chronic Toxicity" (CT). To calculate acute toxicity the Fischer test was used, and to determine chronic toxicity the ANOVA test was used, followed by Dunnett's test (Dunnett, 1955).

\subsection{Statistical analysis of the differences and correlation}

Significant differences and correlations between physical/chemical parameters and the toxicity to C. dubia were established by application of Mann Whitney Test and Pearson Coefficient Correlation, calculated using the SPSS (Statistical Package for Social Science) version 15.0.

\subsection{Water quality classification}

Among the Brazilian regulations related to water resources, the National Environmental Council (CONAMA) Resolution no 357/05 (Brasil, 2005) established limits for several parameters as criteria for quality classification. This Resolution, as well as including physical and chemical parameters, includes the measurement of ecotoxicological effects and thus establishes the maintenance of aquatic life as a criterion for classifying the quality of water bodies. The classification ranges from class 1 (highest quality) to class 4 (low quality) and these class criteria were used to compare the water quality in the present investigation.

\section{Results}

\subsection{Physical and chemical analyses}

Data from physical and chemical analyses from the Sobradinho and Jardim Rivers are summarized in Tables 1 and 2, respectively. P2 and P3 (Sobradinho River) presented a high variation in conductivity. The turbidity parameter presented variation at the three points, with minimum of 0.5 and maximum of $186.0 \mathrm{NTU}$, probably due to seasonality between the driest and wettest periods. At P1 the total hardness showed mean content of $2.3 \mathrm{mg} . \mathrm{L}^{-1} \mathrm{CaCO}_{3}$. There was little variation at all three points on the Jardim River in all the analyses. Higher variations were observed in turbidity at P5 and P6 with standard deviations of 4.9 and 10.8 NTU, respectively. P4 presented total hardness with content below $1.0 \mathrm{mg} . \mathrm{L}^{-1} \mathrm{CaCO}_{3}$ in all months, but $\mathrm{P} 5$ presented a mean of 2.1 and $\mathrm{P} 6$ a mean of 6.6 mg. $\mathrm{L}^{-1} \mathrm{CaCO}_{3}$ in the studied months. Comparing the data from analyses from the two rivers, the conductivity and turbidity variables showed their highest content at P3, downstream from the Sobradinho sewage treatment plant effluent. On the other hand, the DO presented its lowest content at this same point. Data provided in Table 1 show the parameters $\mathrm{DO}$, conductivity, $\mathrm{Cl}^{-}, \mathrm{NO}_{3}^{-}, \mathrm{SO}_{4}^{2-}$ and $\mathrm{Na}^{+}$to be the most indicative of contamination by urban effluents, mainly by the STP.

To better explain the obtained results along of the monitoring, data from meteorological stations

Table 1. Physical and chemical data from three sampling points on the Sobradinho River (Sobradinho, Federal District, Brazil) collected monthly from May 2008 to April 2009.

\begin{tabular}{|c|c|c|c|c|c|c|c|c|c|c|c|c|}
\hline \multirow[t]{2}{*}{ Variable } & \multicolumn{4}{|c|}{ P1 } & \multicolumn{4}{|c|}{ P2 } & \multicolumn{4}{|c|}{ P3 } \\
\hline & Mean & Max & Min & SD & Mean & Max & Min & SD & Mean & Max & Min & SD \\
\hline Temperature ${ }^{\circ} \mathrm{C}$ & 19.8 & $22.1^{* *}$ & $17.0^{*}$ & 1.6 & 20.1 & $23.0_{* *}$ & $17.2^{*}$ & 1.8 & 20.8 & $23.7^{* *}$ & $17.3^{*}$ & 1.9 \\
\hline DO mg. $\mathrm{L}^{-1}$ & 6.7 & $8.5^{*}$ & $4.7^{* *}$ & 1.2 & 5.6 & $7.3^{*}$ & $3.9^{* *}$ & 0.9 & 3.7 & $5.8^{*}$ & $2.2^{* *}$ & 1.5 \\
\hline $\mathrm{pH}$ & 6.1 & $7.1^{*}$ & $4.9^{* *}$ & 0.8 & 6.2 & $6.4^{*}$ & $5.8^{* *}$ & 0.2 & 6.3 & $6.7^{* *}$ & $5.9^{* *}$ & 0.2 \\
\hline $\begin{array}{l}\text { Conductivity } \\
\mu \mathrm{S} . \mathrm{cm}^{-1}\end{array}$ & 5.2 & $9.0^{* *}$ & $1.0^{* *}$ & 2.1 & 60.9 & $85.0^{* *}$ & $35.0^{* *}$ & 12.6 & 141.9 & $198.0^{*}$ & $68.0^{* *}$ & 43.0 \\
\hline Turbidity NTU & 4.5 & $20.0^{* *}$ & $0.5^{*}$ & 7.1 & 41.9 & $333.0^{\star *}$ & $4.3^{*}$ & 92.5 & 47.2 & $224.0^{\star *}$ & $5.3^{*}$ & 74.8 \\
\hline $\begin{array}{l}\text { Hardness } \mathrm{mg} \cdot \mathrm{L}^{-1} \\
\mathrm{CaCO}_{3}\end{array}$ & 2.3 & $4.1^{*}$ & $1.1^{* *}$ & 1.0 & 20.0 & $63.8^{*}$ & $6.9^{* *}$ & 16.7 & 21.6 & $29.9^{*}$ & $15.8^{* *}$ & 4.9 \\
\hline $\mathrm{Cl}^{-} \mathrm{mg} \cdot \mathrm{L}^{-1}$ & 0.23 & $0.37^{*}$ & $0.12^{\star *}$ & 0.09 & 3.33 & $4.83^{*}$ & $1.31^{* *}$ & 1.00 & 6.76 & $10.19^{*}$ & $2.19^{* *}$ & 2.70 \\
\hline $\mathrm{NO}_{3}^{-} \mathrm{mg} \cdot \mathrm{L}^{-1}$ & n.d. & n.d. & n.d. & n.d. & 5.63 & $8.34^{*}$ & $1.53^{* *}$ & 2.51 & 1.62 & $2.70^{* *}$ & $0.49^{*}$ & 0.71 \\
\hline $\mathrm{PO}_{4}{ }^{3-} \mathrm{mg} \cdot \mathrm{L}^{-1}$ & n.d. & n.d. & n.d. & n.d. & n.d. & n.d. & n.d. & n.d. & n.d. & n.d. & n.d. & n.d. \\
\hline $\mathrm{SO}_{4}{ }^{2-} \mathrm{mg} \cdot \mathrm{L}^{-1}$ & n.d. & n.d. & n.d. & n.d. & 0.75 & $2.85^{\star *}$ & $0.26^{*}$ & 0.75 & 12.60 & $21.05^{\star \star}$ & $4.06^{* *}$ & 5.09 \\
\hline $\mathrm{Na}^{+} \mathrm{mg} \cdot \mathrm{L}^{-1}$ & 0.33 & $0.55^{\star}$ & $0.10^{* *}$ & 0.14 & 6.64 & $10.37^{*}$ & $1.67^{* *}$ & 2.60 & 11.25 & $20.61^{*}$ & $3.40^{* *}$ & 5.42 \\
\hline $\mathrm{NH}_{4}^{+} \mathrm{mg} \cdot \mathrm{L}^{-1}$ & n.d. & n.d. & n.d. & n.d. & n.d. & n.d. & n.d. & n.d. & 5.09 & $11.05^{\star}$ & $0.30^{* *}$ & 3.66 \\
\hline $\mathrm{Ca}^{2+} \mathrm{mg} \cdot \mathrm{L}^{-1}$ & 0.72 & $1.37^{* *}$ & $0.36^{* *}$ & 0.30 & 6.70 & $22.25^{\star *}$ & $2.26^{*}$ & 5.78 & 7.06 & $10.27^{* *}$ & $4.89^{*}$ & 1.84 \\
\hline $\mathrm{Mg}^{2+} \mathrm{mg} \cdot \mathrm{L}^{-1}$ & 0.13 & $0.31^{* *}$ & $0.09^{*}$ & 0.10 & 0.80 & $2.02^{\star *}$ & $0.25^{*}$ & 0.56 & 0.96 & $1.13^{* *}$ & $0.75^{*}$ & 0.14 \\
\hline
\end{tabular}

$\left(\mathrm{Max}=\right.$ maximum; Min = minimum; $\mathrm{SD}=$ standard deviation; $n=12$; n.d. $=$ not detected $<0.001$ mg. $\mathrm{L}^{-1} ;{ }^{*} \mathrm{dry}$ period; ${ }^{* *}$ rainy period). 
from Embrapa Cerrados presents the rainfall variations between dry and rainy periods in the monitored year at the studied basins (Figures 3a,b).

\subsection{Total coliforms and E. coli}

In the analysis of microbiological parameters it was observed that P2 and P3 (Sobradinho) presented a high rate of total coliforms in all the sampling months (>2419.6 MPN.100 $\left.\mathrm{mL}^{-1}\right)$, as shown in Table 3. P6 (Jardim) presented a high Most Probable Number (MPN) for total coliforms in the months of May, June and from December to April. For E. coli, P3 (downstream of the Sobradinho sewage treatment plant) presented MPN $\geq 2419.6$ in all months, while P5 and P6 (Jardim) had rates varying between 240.0 and $>2419.6 \mathrm{MPN}$.

\subsection{Toxicity to C. dubia}

Toxicity to C. dubia at the six sampling points is shown in Table 4. From June to August of 2008 the sample from P1 (spring of the Sobradinho River) presented chronic toxicity (CT) and the sample from P2 presented CT in April 2009. P4 and $\mathrm{P} 5$ presented acute toxicity (AT) in January and February 2009, while P4 showed CT in the other months and P5 from August to December of

Table 2. Physical and chemical data from three sampling points on the Jardim River (Planaltina, Federal District, Brazil) collected monthly from May 2008 to April.

\begin{tabular}{|c|c|c|c|c|c|c|c|c|c|c|c|c|}
\hline \multicolumn{13}{|c|}{ Jardim River } \\
\hline \multirow[t]{2}{*}{ Variable } & \multicolumn{4}{|c|}{ P4 } & \multicolumn{4}{|c|}{ P5 } & \multicolumn{4}{|c|}{ P6 } \\
\hline & Mean & Max & Min & SD & Mean & Max & Min & SD & Mean & Max & Min & SD \\
\hline Temperature ${ }^{\circ} \mathrm{C}$ & 20.0 & $21.7^{* *}$ & $17.0^{*}$ & 1.7 & 20.2 & $22.4^{* *}$ & $17.1^{*}$ & 1.8 & 20.0 & $23.1^{\text {** }}$ & $15.9^{*}$ & 2.5 \\
\hline $\mathrm{DO} \mathrm{mg} \cdot \mathrm{L}^{-1}$ & 6.3 & $7.7^{*}$ & $4.0^{* *}$ & 1.4 & 6.9 & $8.2^{*}$ & $4.3^{* *}$ & 1.5 & 7.1 & $9.8^{*}$ & $4.5^{\star \star}$ & 1.7 \\
\hline $\mathrm{pH}$ & 6.4 & $7.9^{*}$ & $5.4^{* *}$ & 0.8 & 6.0 & $7.2^{*}$ & $4.9^{* *}$ & 0.8 & 5.9 & $6.8^{* *}$ & $4.8^{* *}$ & 0.7 \\
\hline $\begin{array}{l}\text { Conductivity } \\
\mu \mathrm{S} . \mathrm{cm}^{-1}\end{array}$ & 2.7 & $12.0^{*}$ & $1.0^{* *}$ & 0.6 & 5.8 & $7.0^{* *}$ & $5.0^{*}$ & 0.7 & 15.2 & $19.0^{* *}$ & $11.0^{*}$ & 2.6 \\
\hline Turbidity NTU & 3.2 & $9.4^{* *}$ & $0.6^{*}$ & 2.6 & 7.5 & $13.8^{* *}$ & $2.2^{*}$ & 4.9 & 12.7 & $35.0^{* *}$ & $4.1^{*}$ & 10.8 \\
\hline $\begin{array}{l}\text { Hardness mg. } \mathrm{L}^{-1} \\
\mathrm{CaCO}_{3}\end{array}$ & $<1.0$ & $<1.0$ & $<1.0$ & $<1.0$ & 2.1 & $4.6^{*}$ & $0.6^{* *}$ & 1.0 & 6.6 & $12.1^{*}$ & $2.8^{* *}$ & 2.5 \\
\hline $\mathrm{Cl}^{-} \mathrm{mg} \cdot \mathrm{L}^{-1}$ & 0.20 & $0.44^{* *}$ & $0.12^{*}$ & 0.10 & 0.40 & $1.11^{*}$ & $0.19^{*}$ & 0.25 & 0.59 & $1.30^{*}$ & $0.28^{*}$ & 0.33 \\
\hline $\mathrm{NO}_{3}^{-} \mathrm{mg} \cdot \mathrm{L}^{-1}$ & 0.06 & $0.22^{*}$ & $0.15^{* *}$ & 0.09 & 0.21 & $0.34^{* *}$ & $0.12^{* *}$ & 0.10 & 0.20 & $0.49^{*}$ & $0.15^{* *}$ & 0.13 \\
\hline $\mathrm{PO}_{4}{ }^{3-} \mathrm{mg} \cdot \mathrm{L}^{-1}$ & n.d. & n.d. & n.d. & n.d. & n.d. & n.d. & n.d. & n.d. & n.d. & n.d. & n.d. & n.d. \\
\hline $\mathrm{SO}_{4}{ }^{2-} \mathrm{mg} \cdot \mathrm{L}^{-1}$ & n.d. & n.d. & n.d. & n.d. & n.d. & n.d. & n.d. & n.d. & n.d. & n.d. & n.d. & n.d. \\
\hline $\mathrm{Na}^{+} \mathrm{mg} \cdot \mathrm{L}^{-1}$ & 0.32 & $0.42^{*}$ & $0.20^{*}$ & 0.08 & 0.57 & $1.35^{\star}$ & $0.32^{* *}$ & 0.30 & 1.17 & $1.97^{* *}$ & $0.77^{* *}$ & 0.41 \\
\hline $\mathrm{NH}_{4}{ }^{+} \mathrm{mg} \cdot \mathrm{L}^{-1}$ & n.d. & n.d. & n.d. & n.d. & n.d. & n.d. & n.d. & n.d. & n.d. & n.d. & n.d. & n.d. \\
\hline $\mathrm{Ca}^{2+} \mathrm{mg} \cdot \mathrm{L}^{-1}$ & n.d. & n.d. & n.d. & n.d. & 0.49 & $1.17^{*}$ & $0.11^{* *}$ & 0.26 & 1.67 & $3.08^{*}$ & $0.66^{* *}$ & 0.67 \\
\hline $\mathrm{Mg}^{2+} \mathrm{mg} \cdot \mathrm{L}^{-1}$ & n.d. & n.d. & n.d. & n.d. & 0.22 & $0.42^{*}$ & $0.08^{* *}$ & 0.09 & 0.58 & $1.06^{*}$ & $0.28^{* *}$ & 0.23 \\
\hline
\end{tabular}

(Max = maximum; Min = minimum; SD = standard deviation; $n=12 ;$ n.d. $=$ not detected $<0.001$ mg. $\mathrm{L}^{-1} ;{ }^{*}$ dry period; ${ }^{* *}$ rainy period).

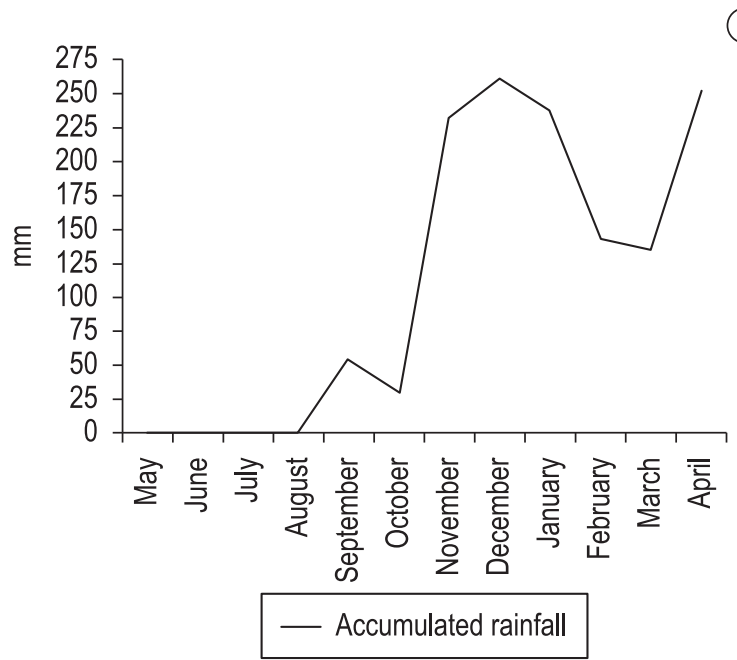

(a)

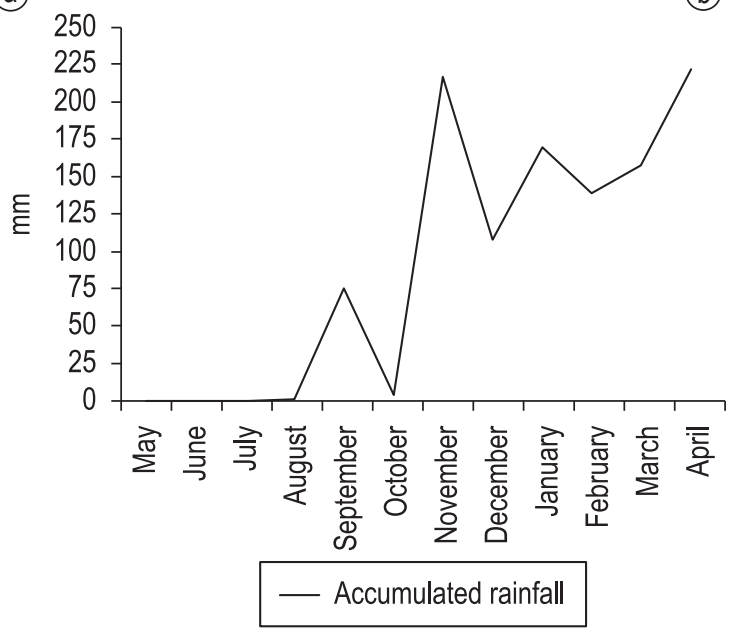

Figure 3. Accumulated rainfall in the studied period in the Sobradinho River basin (a) and in the Jardim River basin (b). Source: Laboratory of Environmental Biophysics at Embrapa Cerrados. 


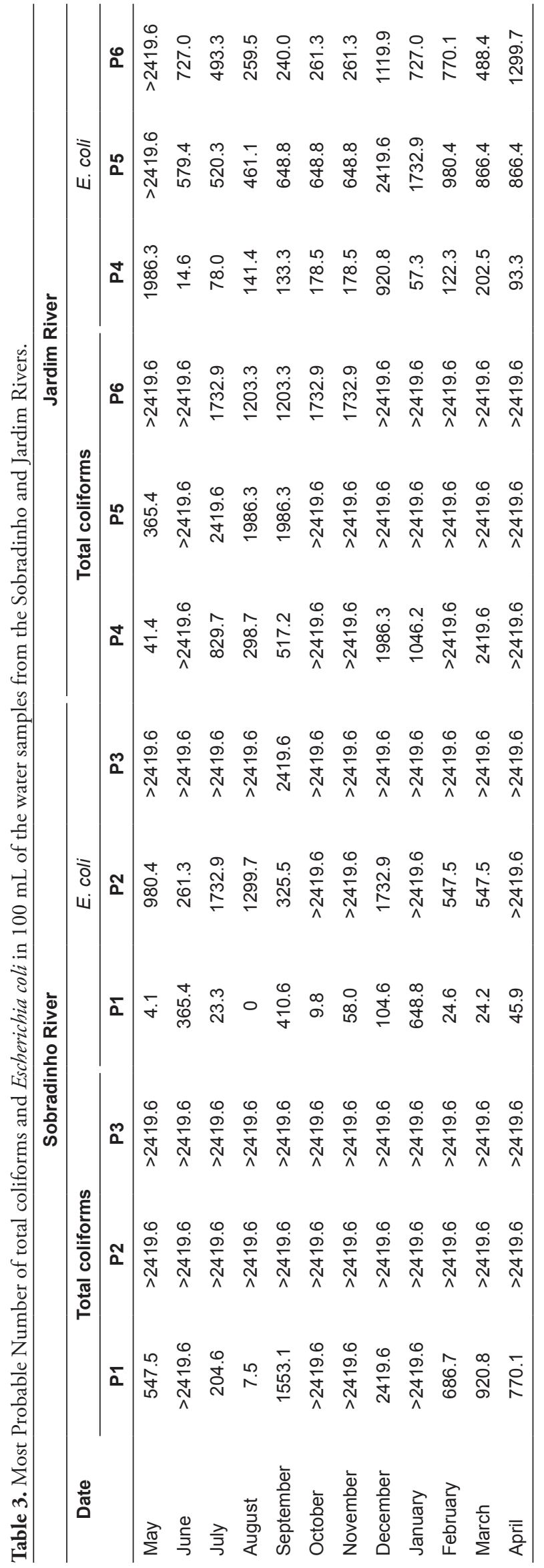


Table 4. Toxicity of water samples to microcrustacean $C$. dubia in the twelve months in study areas.

\begin{tabular}{|c|c|c|c|c|c|c|c|}
\hline \multirow{3}{*}{ Month } & \multicolumn{7}{|c|}{ Toxicity } \\
\hline & \multirow[t]{2}{*}{ Control } & \multicolumn{3}{|c|}{$\begin{array}{l}\text { Sobradinho River } \\
\text { (Urban area) }\end{array}$} & \multicolumn{3}{|c|}{$\begin{array}{c}\text { Jardim River } \\
\text { (Agricultural area) }\end{array}$} \\
\hline & & P1 & P2 & P3 & P4 & P5 & P6 \\
\hline May & NT & NT & NT & NT & CT & NT & NT \\
\hline June & NT & CT & NT & NT & CT & NT & CT \\
\hline July & NT & CT & NT & NT & CT & NT & NT \\
\hline August & NT & CT & NT & NT & CT & CT & NT \\
\hline September & NT & NT & NT & NT & CT & CT & NT \\
\hline October & NT & NT & NT & NT & CT & CT & NT \\
\hline November & NT & NT & NT & NT & CT & CT & NT \\
\hline December & NT & NT & NT & NT & CT & CT & CT \\
\hline January & NT & NT & NT & NT & AT & AT & NT \\
\hline February & NT & NT & NT & NT & AT & AT & NT \\
\hline March & NT & NT & NT & NT & CT & NT & NT \\
\hline April & NT & NT & CT & NT & CT & NT & NT \\
\hline
\end{tabular}

Data were expressed as NT = Non-Toxicity, CT = Chronic Toxicity and AT = Acute Toxicity.

2008. It was observed that in June, July and August the concentrations of calcium and magnesium at P1 were relatively lower than in the other analyzed months, while at $\mathrm{P} 4$ significant concentrations of these elements were not detected (Tables 1 and 2).

\subsection{Susceptibility of C. dubia to a reference substance}

All the assays with positive control (sodium chloride) showed the organism's susceptibility. In the twelve assays carried out, the values obtained for $\mathrm{EC}_{50}$ immobilization were within variability limits (average \pm 2 standard deviation), considered acceptable by the current protocols (Table 5).

To explain the relationships between physical/ chemical parameters obtained in water and the toxic effects observed for $C$. dubia, Table 6 presents a statistical analysis of the obtained data. The Pearson Correlation Coefficient shows parameters that were more related to the toxic phenomenon in a hierarchical sequence (Table 6).

\section{Discussion}

In accordance with the physical, chemical and biological results obtained during the study period, it was confirmed that the water from the Sobradinho River undergoes a considerable reduction in quality as it advances towards the town of Sobradinho. Several authors connect urbanization with the drop in natural water quality (Silva et al., 2009; Nduka and Orisakwe, 2011).

At P1, the source of the Sobradinho River, due to the natural vegetation that still exists and to the protection of the area, the water presented physical and chemical characteristics that are better than at the other two sampling sites, including
Table 5. Acute toxicity and confidence limits of the reference substance sodium chloride (g.L $\mathrm{L}^{-1}$ ) to $C$. dubia after 48 hours exposure over twelve months.

\begin{tabular}{lc}
\hline \multicolumn{1}{c}{ Month } & 48 hours $\mathrm{EC}_{50}$ (g. $\left.\mathbf{L}^{-1}\right)$ \\
\hline May & $1.25(0.98-1.35)$ \\
June & $0.88(0.75-1.03)$ \\
July & $1.15(0.97-1.36)$ \\
August & $0.96(0.79-1.18)$ \\
September & $0.74(0.65-0.89)$ \\
October & $1.33(1.08-1.66)$ \\
November & $1.22(1.09-1.45)$ \\
December & $1.03(0.91-1.19)$ \\
January & $0.89(0.75-1.08)$ \\
February & $0.80(0.73-1.07)$ \\
March & $1.15(0.97-1.36)$ \\
April & $1.01(0.87-1.18)$ \\
Average \pm Standard deviation & $1.03 \pm 0.16$ \\
\hline
\end{tabular}

higher DO, lower conductivity, $\mathrm{NO}_{3}^{-}, \mathrm{SO}_{4}^{2-}, \mathrm{Cl}^{-}$, $\mathrm{Na}^{-}$and $\mathrm{NH}_{4}^{+}$, classifying this point as Class 1 by the Brazilian environmental standards (Brasil, 2005). On the other hand, this point presented low calcium and magnesium content in only some months, which affected the reproduction of the microcrustacean $C$. dubia and the classification based on the ecotoxicity data.

P2 (upstream of the Sobradinho sewage treatment plant) presented low quality mainly related to total coliforms and E. coli, as well as showing significant levels of nitrate, chloride and sodium content, being classified as Class 2 in agreement with CONAMA 357.

These results may be associated with domestic waste thrown out by illicit discharge connections near P2. P3 (downstream of the Sobradinho sewage treatment station) had the worst water quality results, with low DO content, high conductivity, 
Table 6. Correlation between physical/chemical parameters and absence or presence of toxicity to C. dubia by Mann Whitney Test and Pearson Correlation Coefficient.

\begin{tabular}{|c|c|c|c|c|c|c|}
\hline \multirow[t]{3}{*}{ Parameters } & \multicolumn{4}{|c|}{ Toxicity to C. dubia } & \multirow{3}{*}{$\begin{array}{c}\text { Mann } \\
\text { Whitney } \\
\text { Test }\end{array}$} & \multirow{3}{*}{$\begin{array}{c}\text { Pearson } \\
\text { Correlation } \\
\text { Coefficient }\end{array}$} \\
\hline & \multicolumn{2}{|c|}{ Non-toxicity } & \multicolumn{2}{|c|}{ Toxicity } & & \\
\hline & $\mathbf{N}$ & Median & $\mathbf{N}$ & Median & & \\
\hline $\mathrm{Mg}^{2+}\left(\mathrm{mg} \cdot \mathrm{L}^{-1}\right)$ & 47 & 0.47 & 25 & 0.02 & $0.000^{\mathrm{a}}$ & $-0.502^{* *}$ \\
\hline Hardness (mg.L $\mathrm{L}^{-1} \mathrm{CaCO}_{3}$ ) & 47 & 7.80 & 25 & 1.10 & $0.000^{\mathrm{a}}$ & $-0.445^{\star \star}$ \\
\hline Conductivity $\left(\mu \mathrm{S} . \mathrm{cm}^{-1}\right)$ & 47 & 19.00 & 25 & 4.00 & $0.000^{\mathrm{a}}$ & $-0.431^{* *}$ \\
\hline $\mathrm{Ca}^{2+}\left(\mathrm{mg} \cdot \mathrm{L}^{-1}\right)$ & 47 & 2.45 & 25 & 0.26 & $0.000^{\mathrm{a}}$ & $-0.427^{* *}$ \\
\hline $\mathrm{Cl}^{-}\left(\mathrm{mg} \cdot \mathrm{L}^{-1}\right)$ & 47 & 1.30 & 25 & 0.23 & $0.000^{\mathrm{a}}$ & $-0.416^{\star \star}$ \\
\hline $\mathrm{Na}^{+}\left(\mathrm{mg} \cdot \mathrm{L}^{-1}\right)$ & 47 & 1.87 & 25 & 0.39 & $0.000^{\mathrm{a}}$ & $-0.410^{\star *}$ \\
\hline $\mathrm{SO}_{4}^{2-}\left(\mathrm{mg} \cdot \mathrm{L}^{-1}\right)$ & 47 & 0.00 & 25 & 0.00 & $0.002^{\mathrm{a}}$ & $-0.302^{* *}$ \\
\hline $\mathrm{NH}_{4}^{+}\left(\mathrm{mg} \cdot \mathrm{L}^{-1}\right)$ & 47 & 0.00 & 25 & 0.00 & $0.008^{a}$ & $-0.263^{*}$ \\
\hline $\mathrm{NO}_{3}^{-}\left(\mathrm{mg} \cdot \mathrm{L}^{-1}\right)$ & 47 & 0.48 & 25 & 0.12 & $0.000^{\mathrm{a}}$ & $-0.237^{*}$ \\
\hline Turbidity (NTU) & 47 & 9.84 & 25 & 4.00 & $0.003^{a}$ & -0.112 \\
\hline $\mathrm{DO}\left(\mathrm{mg} \cdot \mathrm{L}^{-1}\right)$ & 47 & 5.83 & 25 & 6.89 & 0.062 & - \\
\hline $\mathrm{pH}$ & 47 & 6.15 & 25 & 6.25 & 0.274 & - \\
\hline
\end{tabular}

${ }^{a}$ Differences statistically significant at $\mathrm{p}<0.05 ;{ }^{* *}$ Correlation significant at 0.01 level $\left(2\right.$-tailed); ${ }^{*}$ Correlation significant at 0.05 level (2-tailed).

high chloride, sodium and sulfate content, as well as a high number of total coliforms and E. coli in all the analyzed months, being classified as class 4 by CONAMA 357. These physical and chemical data were very similar to those observed in the Sobradinho River by Shibano et al. (2000). Although phosphate is an important contaminant found in domestic sewage releases, the nondetection of this anion in $\mathrm{P} 3$ can be explained by 95.4\% removal of total phosphorous from the STP effluent, as informed by the Federal District's Environmental Sanitation Company (CAESB, 2008). The efficiency of the sewage treatment already explains the lower contents of nitrate at P3 than at P2. However, all the results observed in $\mathrm{P} 3$ are directly influenced by the effluent of the Sobradinho sewage treatment plant, which has been operating above its capacity for some years. According to the CAESB, the Sobradinho sewage treatment plant was built in 1967 and planned for a secondary treatment capacity of $56 \mathrm{~L} . \mathrm{s}^{-1}$, for a population of 40,000 people. Due to unplanned expansion in the town the quantity of sewage has practically doubled and treatment efficiency could be better (CAESB, 2008).

In the Jardim River the physical and chemical characteristics were considered good, with all these parameters below regulation standards. Despite being natural, the low presence of calcium and magnesium produced toxic effects on $C$. dubia at all points, especially at $\mathrm{P} 4$, the source. In terms of total coliforms and E. coli present, this point showed good water quality, except in May and December of 2008. Without ecotoxicity evaluation, this point could be classified as class 1 by CONAMA, but chronic toxicity observed by the absence of calcium and magnesium classified it as class 4. Issues like this need to be better discussed in environmental forums.

In this basin, which is under agricultural use, the amount of total coliforms and E. coli was lower than that seen in the Sobradinho River, and even the rates seen at P5 and P6 allowed this water for a variety of uses, according to brazilian legislation. The increase noted for this parameter at P5 and P6 compared to P4 may be linked to livestock farming and to the effluent of small untreated quantities of sewage. It may even be accounted for by the presence of unregulated drains and the lack of riparian vegetation.

In this aspect, recent studies have evidenced various sources associated with watershed contamination, both in urban and rural areas (Mallin et al., 2009). However, in rural areas Ragosta et al. (2010) have confirmed a strong association between a decrease in the riparian canopy cover and an increase in fecal bacteria in surface runoff. Oliveira-Filho et al. (2011) also noted a higher efficiency in using E. coli as a bioindicator than in assays with $C$. dubia when urban pollution was evaluated in Lake Paranoá in Brasília, Brazil.

In the current study it was possible to observe that the assays with $C$. dubia were harmed by the low water hardness of the sampled rivers, especially in the headwaters. In the Jardim River (P4, P5 and P6), the hardness was always very low, indicating minimum values of $\mathrm{Ca}^{2+}$ and $\mathrm{Mg}^{2+}$ in the water and 
suggesting a strong similarity with the typical soil of the Brazilian Cerrado (Lopes and Cox, 1977; Furley and Ratter, 1988). At P1 (Sobradinho River), which is an area near the source, this phenomenon was also observed, but with higher values. According to Lasier et al. (2006), there is a weak point in the guidelines for assays dealing with chronic toxicity in aquatic organisms, which is the stress caused by exposing these organisms to a sudden change in water hardness, which combines the concentrations of divalent cations (especially the $\mathrm{Ca}^{2+}$ and $\mathrm{Mg}^{2+}$ ions) in solution. This situation is found when the natural water or effluent samples have significantly lower hardness than that found in the culture of test organisms. These authors evaluated the effects of water hardness and water alkalinity in the culture and in water samples on the reproduction of $C$. dubia. The results showed that reproduction was significantly reduced when the water samples presented lower hardness than the culture water. Harmon et al. (2003) also observed a marked reduction in C. dubia reproduction when the organisms cultured in moderately hard water were exposed to water with low hardness that had come from creeks in South Carolina, USA.

Downstream of P1 and P4 the total hardness values were seen to be higher, especially in the Sobradinho River, suggesting a strong link to urbanization. The slighter increase downstream of $\mathrm{P} 4$ in the Jardim River points to a link with the flux of soil minerals and sediments.

\section{Conclusions}

Data from this work show that the ecosystem of the Sobradinho River basin is considerably disturbed, and that the increase in urban occupation is responsible for the intensification of environmental degradation processes in this basin. Results obtained suggest that DO, conductivity, nitrate, sulfate and E. coli were the best indicators to estimate the type and level of aquatic contamination.

In the Jardim River basin water quality monitoring shows that there is less influence from soil use on the quality parameters, and that effluent rules should be more strictly checked and enforced to improve and maintain standards.

In natural areas (P1/P4), $\mathrm{Ca}^{2+}$ and $\mathrm{Mg}^{2+}$ ions, which are related to the hardness and conductivity, were the most effective indicators for determining anthropic influence on water quality. In the agricultural area none of the observed parameters indicated chemical water contamination, but more observations focused on nutrient ions in water could be important. The fecal coliform indicator (E. coli) was the most effective one for comparing water quality in the two basins, mainly for the urbanized one, while ecotoxicity assays with $C$. dubia were harmed by the natural chemical composition of the water. This aspect should be observed carefully for future assays with environmental samples, especially when comparing parameters used in the culture of test species with those observed in natural environments.

This study clearly showed that the urbanized area exerts more anthropic pressure on the water quality than does the agricultural area.

\section{Acknowledgements}

This work was financed by the National Council for Scientific and Technological Development - CNPq, Project 472223/2007-0. Aline Silva Moraes and Ingrid de Souza Freire received a grant from PIBIC/UniCEUB.

\section{References}

Associação Brasileira de Normas Técnicas - ABNT. 1992. Água: Determinação da dureza total - Método titulométrico do EDTA-Na Método de ensaio. NBR 12621. Rio de Janeiro: ABNT.

Associação Brasileira de Normas Técnicas - ABNT. 2003. Ecotoxicologia aquática: Toxicidade Crônica - Método de ensaio com Ceriodaphnia spp (Cladocera, Crustácea). NBR 13373. Rio de Janeiro: ABNT.

American Public Health Association - APHA. 1998. Standard methods for the examination of water and wastewater. 20th ed. Washington: APHA.

BARROS, JC. 2005. As águas subterrâneas. In BRAGA NETTO, P., MECENAS, VV. and CARDOSO, ES., orgs. APA de Cafuringa: a última fronteira natural do DF. Brasília: SEMARH. p. 53-58.

Brasil. Ministério do Meio Ambiente. Conselho Nacional do Meio Ambiente. 2005. Resolução no 357, de 17 de março de 2005. Dispóe sobre a classificação dos corpos de água e diretrizes ambientais para o seu enquadramento, bem como estabelece as condições e padróes de lançamento de efluentes, e dá outras providências. Diário Oficial da República Federativa do Brasil. Brasília, DF, 18 mar. 2005. Seção 1, p. 58-63.

Companhia de Saneamento do Distrito Federal - CAESB. 2008. Sinopse do Sistema de Esgotamento Sanitário do Distrito Federal. Brasília. Available from: <http:// www.caesb.df.gov.br/_conteudo/siesg/SIESG2008. pdf>. Access in: 18 jun. 2010.

DUNNETT, CW. 1955. Multiple comparison procedure for comparing several treatments with a control. Journal of American Statistical Association, vol. 50, p. 1096-1121. http://dx.doi.org/10.2307/2281208 
FONSECA, FO. 2001. Olhares sobre o Lago Paranoá. Brasília: SEMARH. 425 p.

FURLEY, PA. and RATTER, JA. 1988. Soil resources and plant communities of the Central Brazilian cerrado and their development. Journal of Biogeography, vol. 15, p. 97-108. http://dx.doi.org/10.2307/2845050

HARMON, SM., SPECHT, WL. and CHANDLER, G. T. 2003. A comparison of the daphnids Ceriodaphnia dubia and Daphnia ambigua for their utilization in routine toxicity testing in the southeastern United States. Archives of Environmental Contamination and Toxicology, vol. 45, p. 79-85. PMid:12948176. http:// dx.doi.org/10.1007/s00244-002-0116-8

LASIER, PJ., WINGER, PV. and HARDIN, IR. 2006. Effects of hardness and alkalinity in culture and test waters on reproduction of Ceriodaphnia dubia. Environmental Toxicology and Chemistry, vol. 25, p. 2781-2786. PMid:17022421. http://dx.doi. org/10.1897/05-547R.1

LIMA, JEFW. 2010. Modelagem numérica do fluxo da água no solo e do escoamento de base em uma bacia experimental em área agrícola no cerrado. Brasília: Universidade de Brasília. 312 p. [Tese de Doutorado em Tecnologia Ambiental e Recursos Hídricos].

LIMA, JEFW. and SILVA, EM. 2008. Recursos hídricos do Bioma Cerrado. In SANO, SM., ALMEIDA, SP. and RIBEIRO, JF., orgs. Cerrado: Ecologia e Flora. Brasília: Embrapa Cerrados. p. 90-106.

LOPES, AS. and COX, FR. 1977. A survey of the fertility status of surface soils under 'cerrado' vegetation in Brazil. Soil Science Society American Journal, vol. 41, p. $742-746$.

LUIZ, GP., PARRON, LM., JESUS, WB. and ROCHA, ALA. 2007. Concentraçóes de nitrato e amônio em água subterrânea na bacia do Rio Jardim - DF. p. 31. Available from: <http://www.cpac.embrapa.br/ download/1182/t>. Access in: 25 jun. 2010

MALLIN, MA., JOHNSON, VL. and ENSIGN, SH. 2009. Comparative impacts of stormwater runoff on water quality of an urban, a suburban, and a rural stream. Environmental Monitoring and Assessment, vol. 159, p. 475-491. PMid:19067207. http://dx.doi. org/10.1007/s10661-008-0644-4

MERTEN, GH. and MINELLA, JP. 2002. Qualidade $\mathrm{da}$ água em bacias hidrográficas rurais: um desafio atual para a sobrevivência futura. Agroecologia e Desenvolvimento Rural Sustentável, vol. 3, p. 33-38.

NDUKA, JK. and ORISAKWE, OE. 2011. Waterquality issues in the Niger Delta of Nigeria: a look at heavy metal levels and some physicochemical properties. Environmental Science and Pollution Research, vol. 18, p. 237-246. PMid:20607615. http://dx.doi.org/10.1007/s11356-010-0366-3

OLIVEIRA-FILHO, E. C. and LIMA, J. E. F. W. 2002. Potencial de impacto da agricultura sobre os recursos hídricos na região do Cerrado. Available from: <http:// www.cpac.embrapa.br/download/283/t>. Access in: 18 jun. 2010.

OLIVEIRA-FILHO, EC. and PARRON, LM. 2007. Avaliação de qualidade das águas no Brasil: o Rio Preto examinado. Espaço \& Geografia, vol. 10, p. 279-294.

OLIVEIRA-FILHO, EC., RAMOS, MG., FREIRE, IS. and MUNIZ, DHF. 2011. Comparison between the efficiency of two bioindicators for determining surface water quality in an urban environment. Acta Scientiarum Biological Sciences, vol. 33, n. 3, p. 311-317. http://dx.doi.org/10.4025/actascibiolsci. v33i3.7725

RAGOSTA, G., EVENSEN, C., ATWILl, ER., WALKER, M., TICKTIN, T., ASQUITH, A. and TATE, KW. 2010. Causal connections between water quality and land use in a rural tropical island watershed. Ecohealth, vol. 7, p. 105-113. PMid:20300800. PMCid:2914289. http://dx.doi. org/10.1007/s10393-010-0299-9

SHIBANO, K., AZEVEDO, JA. and OSHIMA, H. 2000. Evaluation of the water quality for environmental conservation in the Federal District, Brazil. In SANO, E., org. Project of sustainable agricultural development and natural resources conservation in the Brazilian Cerrado: technical report 1994-1999. Planaltina: JICA/Embrapa Cerrados. $\mathrm{p}$ 329-337.

SILVA, AM., ROSA, AH., ANTUNES, FM., NOGUEIRA, DP. and LESSA, SS. 2009. Relationship between water quality and land use along a stretch of the Sorocaba river (SP). Journal of the Brazilian Society of Ecotoxicology, vol. 4, p. 65-71. http://dx.doi. org/10.5132/jbse.2009.01.009

World Health Organization - WHO. 2007. New country-by-country data show in detail the impact of environmental factors on health. Available from: <http://www.who.int/mediacentre/news/ releases/2007/pr30/en/index.html>. Acess in: 5 maio 2010.

ZOBY, JLG. and DUARTE, U. 2001. Caracterizaçấo hidrogeológica da bacia do Ribeirão Sobradinho - Brasília (DF). Geologia USP Série Cientifica, vol. 1, p. 79-99. 